DOI: https://doi.org/10.31933/dijms.v2i1

Received: $16^{\text {th }}$ August 2020, Revised: $15^{\text {th }}$ October 2020 , Publish: $17^{\text {th }}$ November 2020

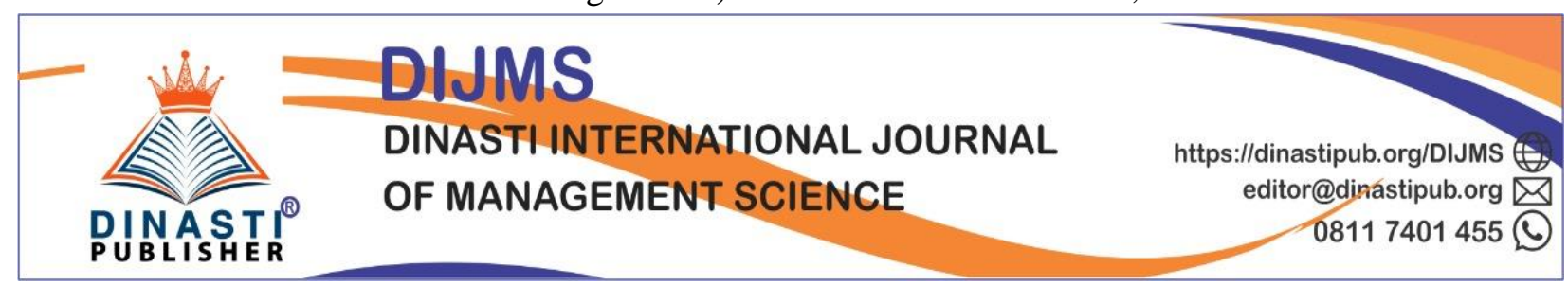

\title{
DETERMINANT ANALYSIS IN PROPERTY STOCKS INDEX AT INDONESIA STOCK EXCHANGE
}

\author{
Alfan Samsuar ${ }^{1}$, Pardomuan Sihombing ${ }^{2}$ \\ 1) Mercu Buana University, Jakarta, Indonesia, alfan09@yahoo.com \\ 2) Mercu Buana University, Jakarta, Indonesia, pardomuan.sihombing@mercubuana.ac.id
}

\section{Corresponding Author: Alfan Samsuar}

\begin{abstract}
This research aims to determine those influence of inflation, interest rates, exchange rates, world oil prices and world gold prices against the property sector stock index which registered In Indonesia Stock Exchange. These population of research were all activities from monthly movement of property sector stock index, inflation, exchange rates, BI interest rates, world oil prices and world gold prices. The sample chosen method by purposive sampling where the researcher gathered its data based on proficiency strategies or personal considerations, selecting data based on these following criteria: 1) Availability of macro economic data that affects shares from property sector during January 2016 to December 2019; and 2) Availability of property stock index data from January 2016 till December 2019. The model used in this research was the Vector Error Correction Model (VECM). With The results showed that: 1) ISP responsiveness to inflation movements where stumbled or shocks that occur on inflation had positive influence towards ISP movements; 2) Responsiveness of ISP to instability or shocks that occur in exchange rates will negatively affect ISP movements; 3) Those responsiveness of ISP to the BI rate movement was responded positively; 4) Based on these results from research conducted, the ISP responded negatively on stumbled or shocks towards oil price movements; and 5) ISP responsiveness to movements or shocks to gold price had been responded positively by the ISP.
\end{abstract}

Keywords: Inflation, interest rates, exchange rates, world oil prices, world gold prices, property sector stock index (ISP).

\section{INTRODUCTION}

Indonesia economy has experienced growth of around 5\% in the last 10 (ten) years (2010 to 2019) which has been greatly supported by the growth of real sector, one of which is the construction sector which includes the property industry. The real sector, especially property industry, it could be used as indicator for the rise of country's macro economic conditions which also prevailed in Indonesia. 


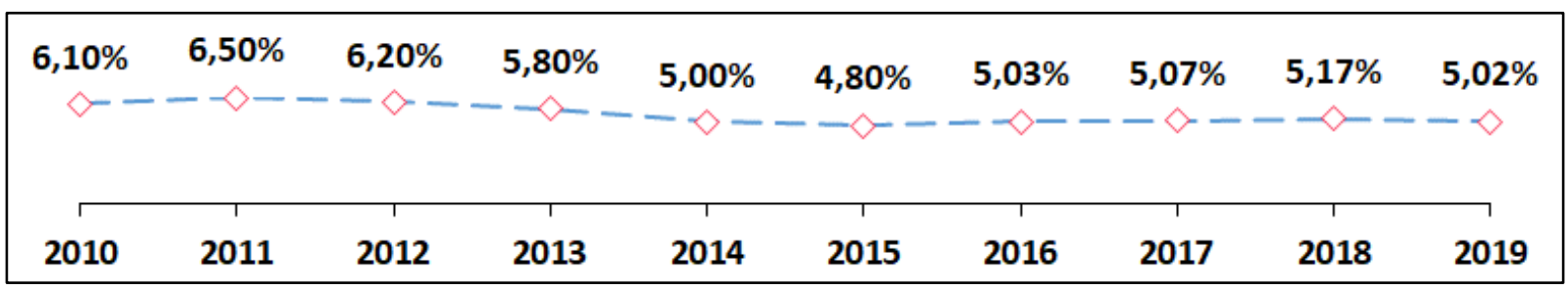

Figure 1. Indonesia's Economic Growth

Source: Bank Indonesia (Indonesian Economic Report)

The global financial crisis that occurred in 2008 was preceded by the collapse of subprime mortgage bonds (mortgages) in which debtors had experienced defaults. The fall in price of subprime mortgage bonds resulted in losses to banks and fund management companies that did not only come from the United States, causing stock prices all over the world to fall, including Indonesia.

There were at least 2 (two) direct influence from global financial crisis on Indonesia economy. First, these influence on the condition of Indonesian stock exchange index where foreign investors still dominate the share ownership on IDX with 52\% at the end of 2018 (CNN Indonesia, 2019), However it causing of stock market to be very sensitive towards global financial conditions because it was related to financial capabilities of capital owners. The second influence is on export-import sector, where the decline in economic performance in Indonesia's export destination countries will also directly impact to Indonesia's export and import.

Global financial crisis that occurred also affected these Macro economic conditions in Indonesia, including interest rate. Interest rates are used as one of fundamental factors to invest. The increase in interest rates makes investors tend to prefer banking investment instruments such as deposits rather than stocks and bonds investment instruments that have lots of risk. This condition created the capital market especially in developing countries like Indonesia, had experienced a shock.

There had probability that the composite stock price index (IHSG) and the primary sector stock price index (IHSP) were also affected by interest rates. From the research results which conducted by Yuanisa (2013), where interest rates had significant and negative influence against IHSG. Meanwhile, research that conducted by Taufiq and Kefi (2015), shows that interest rates had negative and significant impact on IHSG. There are differences from results whom conducted by Aliyah (2016), it shows that interest rates had positive and significant impact on IHSG.

The macro economic variable which also affects stock price changes is foreign exchange rate. The increase in interest rates as a result from global financial crisis resulted in depreciation of local currency, was indicated a weakening of economy so investors will be aware when investing their funds, resulting in reduced demand for stocks which causing a decline in stock prices.

From these results from research whom conducted by Kewal (2012), it shows that exchange rate had negative and significant impact towards IHSG. However, the research results from Kusuma and Badjra which said that exchange rate had positive and significant impact towards IHSG. Another factor that also affected by global financial crisis and would affect the movement of IHSG and ISP values was inflation. High inflation causes people's purchasing power to decline and the price of production factors to increase, therefore inflation is the main reason for investors to fund to protect property values from inflation rate so they could continue to maintain their purchase power. 
From these results from research conducted by Taufiq and Kefi (2015), said where inflation had significant and positive influence on IHSG. While the results from research whom conducted by Maurina (2015), said that inflation rate had positive and insignificant impact towards IHSG . Different results were shown from research that conducted from Sunardi and Ula (2017) showing that inflation had negative and significant influence towards IHSG.

Other macro economic factors whixh had impact towards the movement of IHSG value were world oil prices and world gold prices. Crude oil is an indicator that affects the global economy, usually price standard is West Texas Intermediate (WTI). Meanwhile, gold is one of the most preferred forms of investment because it tends to be risk free because its value is stable and rising. The benchmark which common used as reference price for gold was formed on Metal Exchange Market in London, which is the London Metal Exchange (LME).

From these results from research which conducted by Oktarina (2016), stated that world oil price had negative influence towards IHSG, while the world gold price had positive impact towards IHSG. Research results from Fardiansyah Siagian and Sihombing (2018) stated that world oil price had positive influence towards IHSG and world gold prices had positive impact over IHSG.

According to background description that presented above and from several prior research result there still had research gap with different results. The purpose to carry out empirical examination was to proved that relationship between these variables whether partial or together or both, directly or indirectly or both, as well as positive or negative. Therefore it is interesting to investigate furthermore regarding about the relationship between these variables which from interest rates, exchange rates, inflation, world oil prices, world gold prices and IHSG. Furthermore, this research use the sectoral of IHSG, namely property stock index (ISP), this because the ISP has opposite movement from IHSG. Therefore created the research with title "Determinant Analysis in Property Stocks Index at Indonesia Stock Exchange".

\section{THEORETICAL REVIEW Portfolio}

Zubir (2011) argues that stock portfolio is an investment consisted of various shares from different companies with hope that if one stock decreased, the others would increased, then the investment will not experience loss.

\section{Arbitrage Pricing Theory (APT)}

According to Zubir (2011), APT is an approach in which determining the price of an asset which not only based on one variable, but many variables. In APT, to gained the expected profit, investors do not need to identify market portfolio because its possible to use more than one variable. The APT model for systematic risk estimation of stocks could be drawn as its follows (Tandelilin, 2010):

$\mathrm{Ri}=\mathrm{ai}+\mathrm{bi}_{1} \mathrm{~F}_{1}+\mathrm{bi}_{2} \mathrm{~F}_{2}+\ldots+$ bin $\mathrm{Fn}+\mathrm{ei}$

The APT model for calculating these expected stock returns could be seen as its follows (Tandelilin, 2010):

$E(R i)=R f+B i_{1}\left(E\left(F_{1}\right)-R f\right)+b_{2}\left(E\left(F_{2}\right)-R f\right)+\ldots+b i n(E(F n)-R f)$

\section{Capital Market}

According to Law No.8 of 1995 that concerned about Capital Market, could said that Stock Exchange is a party that organizes and provides a system and / or means by bringing together other parties' buying and selling offers for the purpose of trading Securities between them. 


\section{Stock}

Shares are proof of ownership from company as a claim on company's income and assets. Tandelilin (2010) stated that shares are proof of ownership to assets of the company that publishing in form of shares.

\section{Composite Stock Price Index (IHSG)}

The Stock Price Index which stated by Sawidji is a summary of simultaneous and complex impact on various influencing factors, especially economic phenomena. According to Masodah (2012), the Stock Price Index functions as an indicator on stock market trends that describes market conditions in certain conditions, whether the market is active and sluggish, index movement is an important indicator for investors to determine whether they will sell, hold, or buy shares in certain amount.

\section{Inflation}

According to Irham (2015), inflation was an event that describes a situation and condition where the price of goods had increased and the currency has weakened. In economics, inflation is a process of increasing prices in general and continuously related to market mechanisms which could be caused by various factors, such as, an increased in public consumption, excess liquidity in market that triggered consumption or even speculation, including the consequences of not smooth distribution of goods.

\section{Exchange Rate}

Sukirno (2009) stated that exchange rate is amount of domestic money needed to buy or obtain one unit of foreign currency. Exchange rates could be calculated by following these formula:

$\mathrm{Q}=S \frac{P}{P_{*}^{*}}$

\section{Interest Rate Parity Theory (IRP)}

IRP is an equilibrium condition where the difference in interest rates between two foreign currencies is offset by the difference between the forward rate and the spot rate. In IRP, the relationship between forward premium (or discount) and the difference in interest rates is formulated as follows:

$\mathrm{P}=\frac{F-S}{S}=i h-i f$

The greater the difference in foreign interest rates over domestic interest rates, the greater the forward discount generated by IRP model.

\section{Interest Rate}

According to Hasyim (2016), he said that interest rate is the value or price that must be paid by borrowers or users to obtain funds from fund providers or owners within mutually agreed period of time. Classical economists argued that the supply and demand for investment in capital market would determines the interest rate.

\section{Theoretical Framework and Hypothesis}

Based on theory and several prior reseaech, the provisional conclusions are the inflation rate, interest rate, exchange rate, world oil price and world gold price each of them had affect to ISP.

H1: Inflation rate had negative influence on ISP 
H2: Interest rate had negative impact towards ISP

H3: Exchange rates had negative influence towards ISP

H4: World oil prices had negative impact against ISP

H5: World gold price had negative influence over ISP.

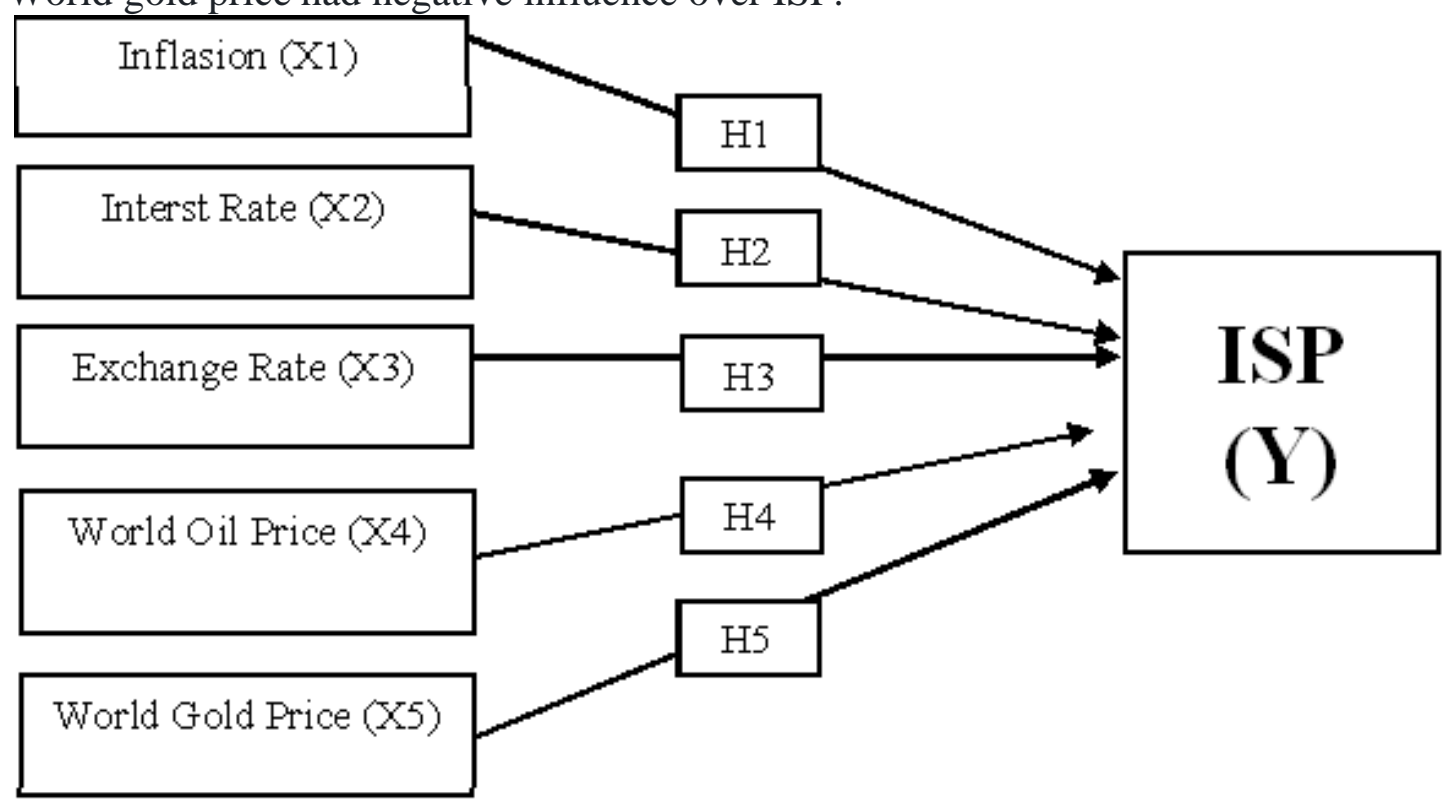

Figure 2. Theoretical Framework

\section{RESEARCH METHODS}

This research used research type of quantitative approach. This research consists of three independent variables and one dependent variable. In this research, the independent variables are inflation, interest rates, exchange rates, world oil prices, and world gold prices, while dependent variable is property sector stock index (ISP).

Population from research were all monthly movement activities from property sector stock index, inflation, exchange rates, BI interest rates, world oil prices and world gold prices. The sample chosen method used purposive sampling where the researcher choose data based on proficiency strategies or personal considerations, selected data based on these following criteria: 1) Availability of macro economic data that will influence the property sector stocks from January 2016 till December 2019; and 2) Availability of property stock index data from January 2016 to December 2019.

Data used in this research topic were secondary data as endogenous variables in form of monthly data. Data gathered was obtained from data that published in general from January 2016 to December 2019. Research on these determinants of property sector stock index will be carried out by time series data with the Vector Auto Regression (VAR) approach if the data used stationary and there's no cointegration or the Vector Error Correction Model (VECM) approach if the data used was found to be not stationary but there had cointegration.

\section{RESULT AND DISCUSSION}

\section{Data Stationarity Test}

The first step that must be taken in estimating these economic model using time series data is by examined the data stationarity with the unit root test. ADF test results was indicated that the data is not stationary at the same level or grade. Overall data, stationary at the first level or first difference (1st Diff) for all variables in these research. 
Table 1. ADF Test Method of Stationary Test Results

\begin{tabular}{ccccccc}
\hline & & \multicolumn{4}{c}{ Stationarity variable test by ADF test method } \\
\cline { 3 - 6 } No & Variable & \multicolumn{3}{c}{ Level } & \multicolumn{3}{c}{ First Difference } & Level \\
\cline { 3 - 5 } & & t stat & p-Value & t stat & p-Value & Stationer \\
\hline 1. & ISP & $-1,885$ & 0,3362 & $-6,668$ & 0,0000 & $1^{\text {st }}$ Diff \\
2. & INF & $-2,308$ & 0,1737 & $-6,637$ & 0,0000 & $1^{\text {st }}$ Diff \\
3. & Kurs & $-1,704$ & 0,4228 & $-9,277$ & 0,0000 & $1^{\text {st }}$ Diff \\
4. & SBI & $-1,304$ & 0,6195 & $-6,281$ & 0,0000 & $1^{\text {st }}$ Diff \\
5. & OP & $-2,479$ & 0,1269 & $-6,206$ & 0,0000 & $1^{\text {st }}$ Diff \\
6. & GP & $-1,505$ & 0,5225 & $-7,342$ & 0,0000 & $1^{\text {st }}$ Diff \\
\hline
\end{tabular}

Source: Data Processed Result

\section{Determination of the Optimum Lag Length}

Choice of lag length by compared those criteria of Likelihood Ratio (LR), Akaike Information Criterion (AIC), Schwarz Information Criterion (SC), Final Prediction Error (FPE) and Hannan-Quinn Information Criterion (HQ). Based on these optimum lag test result, it shows that in this research model the optimum lag was 2 because it was significant based on 3 statistical criteria, namely: LR, FPE, and AIC. Determination of optimum lag length aims to determine the optimal type of long-term cointegration.

Table 2. Output Lag Order Selection Criteria

\begin{tabular}{ccccccc}
\hline Lag & LogL & LR & FPE & AIC & SC & HQ \\
\hline 0 & 234,0488 & NA & $1,99 \mathrm{e}-12$ & $-9,915167$ & $-9,676648$ & $-9,825816$ \\
1 & 411,1719 & 300,3392 & $4,37 \mathrm{e}-15$ & $-16,05095$ & $-14,38132^{*}$ & $-15,42550^{*}$ \\
2 & 451,8902 & $58,42186^{*}$ & $3,86 \mathrm{e}-15^{*}$ & $-16,25610^{*}$ & $-13,15536$ & $-15,09454$ \\
\hline
\end{tabular}

Source: Data Processed Result

\section{Stability Test}

The stability test used in this research was the stability condition check approach through the roots of characteristic polynomial. Based on these stability test result, it shows that the invers roots value of VAR model did not had modulus value which greater than one. It could be Said that VAR model with optimal lag length of 2 was stable. In other words, that VAR model in this research filled the stability requirements.

Table 3. Roots of Characteristic Stability Polynomial Test Results

\begin{tabular}{cc}
\hline Root & Modulus \\
\hline 0,953616 & 0,953616 \\
$0,851088-0,169318 \mathrm{i}$ & 0,867767 \\
$0,851088+0,169318 \mathrm{i}$ & 0,867767 \\
$0,646334-0,429677 \mathrm{i}$ & 0,776125 \\
$0,646334+0,429677 \mathrm{i}$ & 0,776125 \\
$-0,483805-0,366112 \mathrm{i}$ & 0,606717 \\
$-0,483805+0,366112 \mathrm{i}$ & 0,606717 \\
0,548129 & 0,548129 \\
0,267999 & 0,267999 \\
$-0,115502-0,190074 \mathrm{i}$ & 0,222416 \\
$-0,115502+0,190074 \mathrm{i}$ & 0,222416 \\
0,020617 & 0,020617 \\
\hline
\end{tabular}

Source: Results of Data Processed 


\section{Johansen Cointegration Test}

The purpose of these Johansen cointegration test was to find out whether set of variables in a research model is co-integrated or has an equilibrium relationship in the long run. The results from this Johansen cointegration test based on trace statistics was indicated that the variables in this research model had cointegration. Cointegration level was at 1 cointegration, this is based on the trace statistic cointegration probability value $<5 \%$.

Table 4. Results of Johansen Cointegration Trace Statistics

\begin{tabular}{ccccc}
\hline Hypothesized & Eigenvalue & Trace Statistic & 0,05 Critical Value & Prob \\
\hline None & 0,666442 & 121,8669 & 103,8473 & 0,0019 \\
At most 1 & 0,497608 & 72,45964 & 76,97277 & 0,1050 \\
At most 2 & 0,338062 & 41,48278 & 54,07904 & 0,3980 \\
At most 3 & 0,234413 & 22,91654 & 35,19275 & 0,5339 \\
At most 4 & 0,171346 & 10,89651 & 20,26184 & 0,5521 \\
At most 5 & 0,052749 & 2,438624 & 9,164546 & 0,6898 \\
\hline
\end{tabular}

Source: Results of Data Processed

Level of cointegration between Johansen Cointegration Trace Statistic method (Table 4) and Max-Eigenvalue Statistic method (Table 5) has similiar cointegration value, which is at level 1 cointegration, therefore cointegration model in this research was stable. These following are the results from cointegration test with Max-Eigenvalue Statistic method:

Table 5. Results of Johansen Cointegration Max-Eigenvalue Statistic

\begin{tabular}{ccccc}
\hline Hypothesized & Eigenvalue & Max-Eigen Statistic & 0,05 Critical Value & Prob \\
\hline None $^{*}$ & 0,666442 & 49,40729 & 40,95680 & 0,0045 \\
At most 1 & 0,497608 & 30,97686 & 34,80587 & 0,1336 \\
At most 2 & 0,338062 & 18,56624 & 28,58808 & 0,5279 \\
At most 3 & 0,234413 & 12,02003 & 22,29962 & 0,6529 \\
At most 4 & 0,171346 & 8,457886 & 15,89210 & 0,4940 \\
At most 5 & 0,052749 & 2,438624 & 9,164546 & 0,6898 \\
\hline
\end{tabular}

Source: Results of Data Processed

The results from Johansen cointegration test (Table 5) based on Max-Eigenvalue Statistic number was indicate that there has cointegration in this research model. According to value of the Max-Eigenvalue cointegration probability there is 1 cointegration which has a value below $5 \%(<5 \%)$. Thus, the results from this cointegration test was indicated that between the movements / changes in variables of model there had relationship or attachment, so long-term estimates could be made up. Because there had cointegration between these variables, so the model used were the model from Vector Error Correction Model (VECM).

\section{Vector Error Correction Model (VECM)}

The results of these stationarity test had shows that overall data was stationary at first difference level and there had cointegration in the dynamic regression model, so the Vector Error Correction Model (VECM) is the right model to be used in this research. The VECM model in this research used lag 2 based on the results from optimum lag length test. Created a VECM model was also applied because the lack of theory related to these variables in the model.

The estimation results from VECM model, on VECM model was explained that the relationship between independent variables (inflation, exchange rates, interest rates, oil prices 
and gold prices) towards dependent variable (Property Sector Index), Beside that, looking at these relationship of dependent variable itself in the model, such as variable ISP to ISP with cointegration value in VECM model had described that usefulness of lag in the model. Based on optimum lag test result, the use of cointegration in this model were also based on these results from optimum lag test, which is 2 lags, so the cointegration value also used cointegration level 1.

Table 6. Estimation Results of Vector Error Correction Model (VECM)

\begin{tabular}{|c|c|c|c|}
\hline \multicolumn{2}{|c|}{ Long Term Estimates } & \multicolumn{2}{|c|}{ Short Term Estimates } \\
\hline $\begin{array}{l}\text { Variable } \\
\text { Indicator }\end{array}$ & $\begin{array}{c}\text { t-stat } \\
\text { Coefficient }\end{array}$ & $\begin{array}{l}\text { Variable } \\
\text { Indicator }\end{array}$ & $\begin{array}{c}\text { t-stat } \\
\text { Coefficient }\end{array}$ \\
\hline \multirow{2}{*}{$\operatorname{LogISP}(-1))$} & \multirow{2}{*}{1.00000} & $\mathrm{D}(\log \operatorname{ISP}(-1))$ & $\begin{array}{l}0.142 \\
0,596 \\
\end{array}$ \\
\hline & & $\mathrm{D}(\log \mathrm{ISP}(-2))$ & $\begin{array}{l}-0,394 \\
-1,971 \\
\end{array}$ \\
\hline \multicolumn{2}{|c|}{ Inflation } & \multicolumn{2}{|c|}{ Inflation } \\
\hline \multirow{2}{*}{$\operatorname{INF}(-1))$} & \multirow{2}{*}{$\begin{array}{c}0,199 \\
9, .014^{* * *}\end{array}$} & $\mathrm{D}(\mathrm{INF}(-1))$ & $\begin{array}{l}0,036 \\
1,064 \\
\end{array}$ \\
\hline & & $\mathrm{D}(\mathrm{INF}(-2))$ & $\begin{array}{l}0,030 \\
0,876\end{array}$ \\
\hline \multicolumn{2}{|c|}{ Exchange Rate } & \multicolumn{2}{|c|}{ Exch ange Rate } \\
\hline \multirow{2}{*}{$\operatorname{LogKurs}(-1))$} & \multirow{2}{*}{$\begin{array}{l}0,223 \\
0,493\end{array}$} & $D(\operatorname{LogKurs}(-1))$ & $\begin{array}{c}1,45 \\
1,798\end{array}$ \\
\hline & & $\mathrm{D}(\log \operatorname{Kurs}(-2))$ & $\begin{array}{l}0,078 \\
0,428\end{array}$ \\
\hline \multicolumn{2}{|c|}{ Interest Rate } & \multicolumn{2}{|c|}{ Inter est Rate } \\
\hline \multirow{2}{*}{$\mathrm{SBI}(-1))$} & \multirow{2}{*}{$\begin{array}{c}0,098 \\
4,933^{* * *}\end{array}$} & $\mathrm{D}(\mathrm{SBI}(-1))$ & $\begin{array}{c}0,078 \\
2,246 * * *\end{array}$ \\
\hline & & $\mathrm{D}(\mathrm{SBI}(-2))$ & $\begin{array}{l}0,013 \\
0,406 \\
\end{array}$ \\
\hline \multicolumn{2}{|c|}{ Oil Price } & \multicolumn{2}{|c|}{ Oil Price } \\
\hline \multirow{2}{*}{$\log O P(-1))$} & \multirow{2}{*}{$\begin{array}{c}0,825 \\
6,929 * * * *\end{array}$} & $\mathrm{D}(\log \mathrm{OP}(-1))$ & $\begin{array}{l}0,015 \\
0,163 \\
\end{array}$ \\
\hline & & $\mathrm{D}(\log \mathrm{OP}(-2))$ & $\begin{array}{l}0,116 \\
1,326 \\
\end{array}$ \\
\hline \multicolumn{2}{|c|}{ Gold Price } & \multicolumn{2}{|c|}{ Gold Price } \\
\hline \multirow{2}{*}{$\log G P(-1)$} & \multirow{2}{*}{$\begin{array}{c}-0,609 \\
-5,482 * * *\end{array}$} & $\mathrm{D}(\log \mathrm{GP}(-1))$ & $\begin{array}{c}0,538 \\
2,158^{* * *}\end{array}$ \\
\hline & & $\mathrm{D}(\log \mathrm{GP}(-2))$ & $\begin{array}{l}0,368 \\
1,651\end{array}$ \\
\hline \multicolumn{4}{|c|}{ VECM Estimation } \\
\hline \multicolumn{2}{|c|}{ CointEq1 } & \multicolumn{2}{|c|}{$\begin{array}{c}-0,382 \\
-2,262 * * *\end{array}$} \\
\hline \multicolumn{2}{|c|}{ Constanta } & \multicolumn{2}{|c|}{$\begin{array}{c}-8,396 \\
-2,046 * * *\end{array}$} \\
\hline \multicolumn{2}{|c|}{ F-Count } & \multicolumn{2}{|c|}{$1,311^{\text {*** }}$} \\
\hline \multicolumn{2}{|c|}{ Adj R-squared } & \multicolumn{2}{|c|}{0,329} \\
\hline
\end{tabular}

Source: Data Processed Results 
1) Inflation variable in these short term had no influence on property sector index for both lag 1 and 2, this could be seen from the t-value <t-table for the short term. In long run, inflation had positive impact towards property stock index with t-value in the long run $>\mathrm{t}$ table.

2) From results show that t-value of exchange rate variable for both short and long term < compared to t-table value, so exchange rate variable had no influence to property stock index.

3) Sensitivity of interest rates in influenced these property stock index that could be shown in short term (for lag 1) and in the long run the t-count value from interest rate variable > compared to t-table, which means that interest rates had an affect towards property stock index for short and long term.

4) The oil price variable had t-count $>t$-table value, meaning that oil price had an influence towards property stock index, but these influence was positive and only occurs in long term.

5) The gold price variable had t-value > t-table for both long and short term (lag 1), therefore gold price had influence against property stock index. A negative coefficient value was indicates that gold price was increased, property stock index will decrease.

\section{Impulse Response Function (IRF)}

This analysis is short-term and long-term simulation of the impulse response for variable due to shocks that occur in independent variable. If there has shock to inflation, the response to property stock index will be negative during these observation period (10 months) and this could be seen in Figure 3 from period 1 to period 10, the response to property stock index was negative. This shows that if there had an increased in the price of domestic goods, investors will tend to hold their investment in property stocks and turn to savings as precaution in the face of uncertainty in the future.

Response to Cholesky One S.D. Innovations

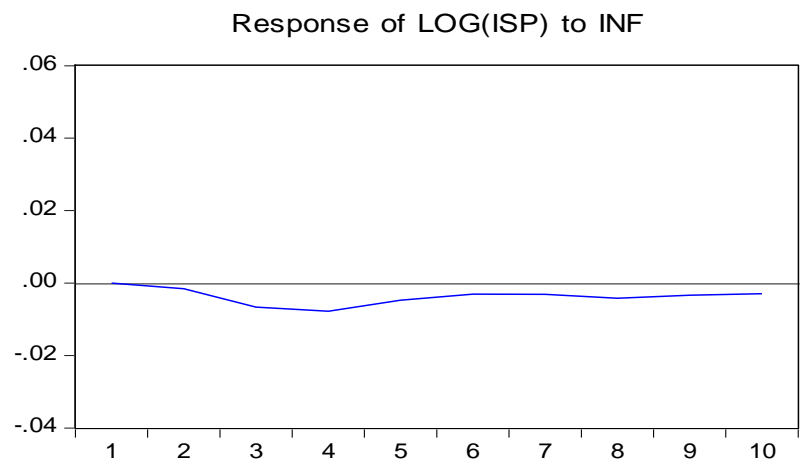

Figure 3. ISP Responsed on INF

Exchange rates are another macro economic variable that had influenced towards ISP movements. If there has instability in rupiah exchange rate, the property stock index will respond negatively. Figure 4 explained that during these observation period (10 months) the property stock index shown negative response from first to the tenth period. The instability in exchange rate would have an impact towards customers and producers, especially for producers whose production factors depend on foreign sources, which will increase their production costs. The increase in production costs will encourage producers to increase the price of goods, resulting in increase in price of goods in the market. The increase in price of goods caused investors to hold their investment in property shares. 
Response to Cholesky One S.D. Innovations

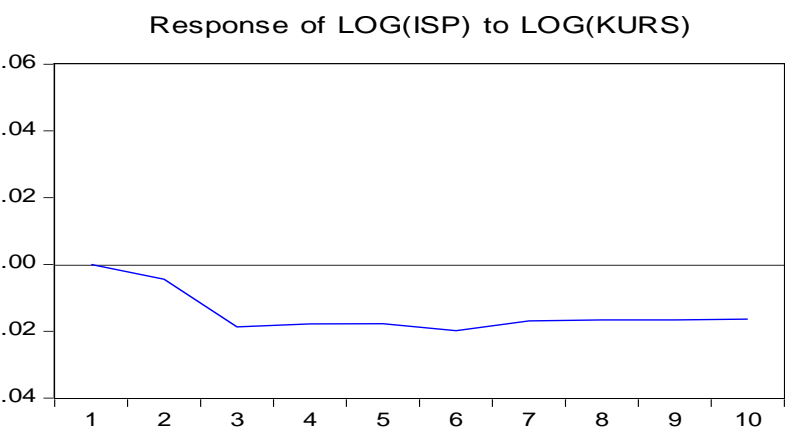

Figure 4. ISP Responsed on Exchange Rates

Figure 5 shows positive response of property stock index to shocks in interest rates from first to tenth periods. Global uncertainty had prompted monetary policy makers to adjust interest rates in order to triggered domestic economic growth. Adjustments to interest rates encourage investors to keep investing in property stocks, this could be seen from these positive response of property stock index during these observation period.

Response to Cholesky One S.D. Innovations

Response of $\mathrm{LOG}(\mathrm{ISP})$ to $\mathrm{R}$

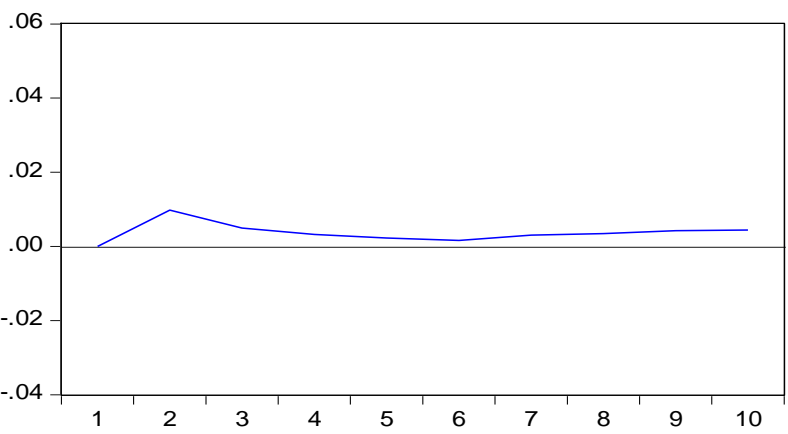

Figure 5. ISP Responsed on BI Rate

During these observation period, from first to tenth period, when there was shock to oil price, the property stock index would respond negatively. The increase in oil prices will affect domestic production, which mostly used fuel oil as its production factor. The increased in production costs will encourages producers to increase the price of their goods which in results of inflation. The increase in price of goods prompted investors to hold back their investment in property shares, resulting in a disinvestment in property shares.

Response to Cholesky One S.D. Innovations

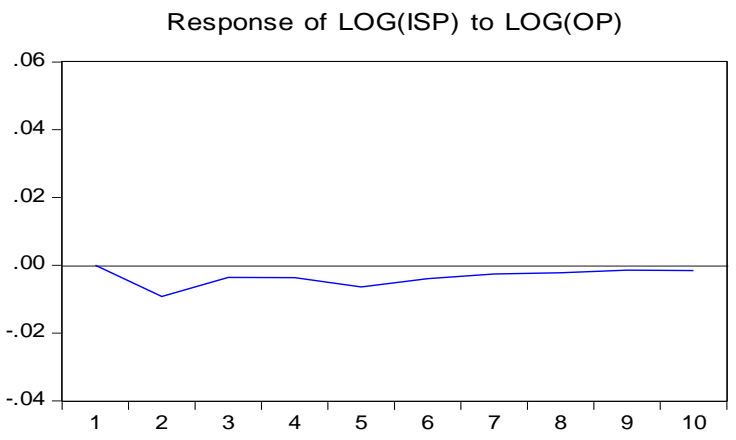

Figure 6. ISP Responsed on OP 
Amid global uncertainty, it is possible to experienced shock in gold price. When the gold price had experienced shocks, it could be breath of fresh air to property stocks because investors will divert their investment funds to other sectors, one of that is property stocks and this was evidenced by Figure 4.5, such as when shock occured in gold price, the property stock index will respond positively to first period until tenth period.

Response to Cholesky One S.D. Innovations

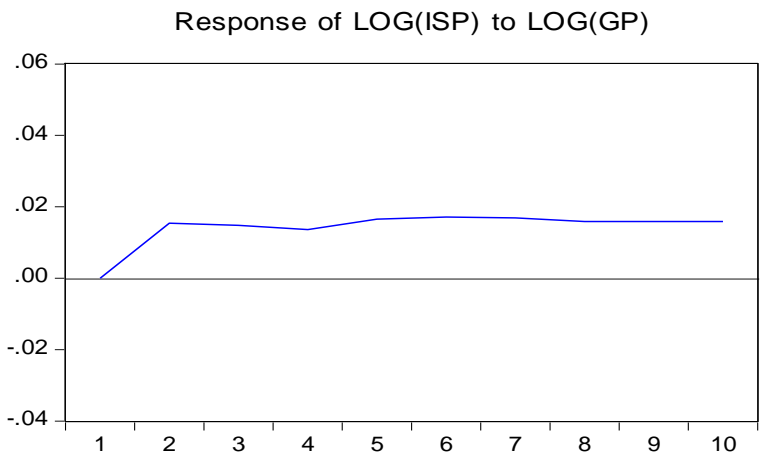

Figure 7. ISP Responsed on GP

\section{Forecasting Error Variance Decomposition (FEVD)}

Forecast Error Variance Decomposition (FEVD) is a method that could be used to see how changes in variable were indicated by changes in error variance which influenced by other variables.

FEVD analysis explained that the relationship between the property stock index (ISP), inflation (INF), exchange rate / exchange rate, interest rate (SBI), oil price (OP) and gold price (GP). These test results was illustrated the prediction of percentage contribution to ISP variable variants to changes in INF, Kurs, SBI, OP and GP variables. In first period that the property stock index was explained by these variable itself $100.00 \%$.

Table 7. Results of Forecasting Error Variance Decomposition

\begin{tabular}{|c|c|c|c|c|c|c|}
\hline Period & ISP & INF & Kurs & SBI & OP & GP \\
\hline 1 & 100,000 & 0,000 & 0,000 & 0,000 & 0,000 & 0,000 \\
\hline 2 & 87,981 & 0,048 & 0,556 & 2,677 & 2,209 & 6,528 \\
\hline 3 & 80,577 & 0,760 & 6,643 & 2,195 & 1,643 & 8,182 \\
\hline 4 & 78,931 & 1,235 & 8,763 & 1,702 & 1,312 & 8,057 \\
\hline 5 & 78,289 & 1,110 & 9,434 & 1,314 & 1,315 & 8,539 \\
\hline 6 & 77,545 & 0,937 & 10,395 & 1,065 & 1,128 & 8,930 \\
\hline 7 & 77,419 & 0,837 & 10,529 & 0,960 & 0,976 & 9,278 \\
\hline 8 & 77,503 & 0,806 & 10,569 & 0,898 & 0,855 & 9,368 \\
\hline 9 & 77,529 & 0,757 & 10,618 & 0,886 & 0,756 & 9,453 \\
\hline 10 & 77,480 & 0,711 & 10,674 & 0,886 & 0,682 & 9,566 \\
\hline
\end{tabular}

\section{CONCLUSION AND SUGGESTION}

\section{Conclusion}

From these research results which has been done, independent variables for inflation, exchange rates, BI rate, oil prices, and gold prices generally could impact those property stock index for long term. Based on these results obtained from the impulse response function (IRF) and variance decomposition (FEVD), each of determinant factor would shocks and influence towards ISP as follows: 
1) Inflation

Based on these results from data processed, it could be seen that responsiveness of ISP to inflation movements where stumble or shocks that occur in inflation had positive influence on ISP movements. Meanwhile, from these analysis of variance decomposition by inflation variable to contribute towards movement of ISP, it was found that these contribution to inflation was $7.11 \%$. The size of this contribution was an indication that inflationary movements had an influence against ISP movements.

2) Exchange Rate

Based on statistical analysis result, it could be seen that responsiveness of ISPs to instability or shocks that occur in exchange rates will negatively affect ISP movements. Meanwhile, when viewed from these results of analysis on variance decomposition, the exchange rate variable gave the most dominant contribution compared to other independent variables. This concludes that exchange rate movements had an influence on ISP movements.

3) BI Rate

From these analysis, it was found that responsiveness of ISP to BI rate movement was responded positively, this means that interest rate adjustments encourage investors to continue investing in property stocks. Meanwhile, from these analysis of variance decomposition on BI rate variable, it contributed $8.86 \%$ to ISP movement. The amount of these contribution is an indication that BI rate movement had impact over ISP movement.

4) Oil Price

Based on these research results that conducted, ISP responded negatively stumble or shocks to oil price movements. The price of increase will push production cost to increase until goods price were Increased. The increase in price makes investors hold back investment in property stocks. Meanwhile, the contribution to ISP movement based on variance decomposition analysis for oil price variable had contribution to $6.82 \%$. This was indicated that oil price movements had impact towards ISP movements.

5) Gold Price

From these analysis, it was found that ISP's responsiveness to movements or shocks over gold price was responded positively by ISP. Gold could be an option in invest because the risk is relatively low compared to stock investment, however if shock occurs in gold price, investors will shift their investment to other sectors, including property stocks. Meanwhile, from these analysis of variance decomposition on gold price variable towards ISP movement, these contribution to gold price movement is a factor that also dominant compared to other variables.

\section{Suggestion}

From these conclusions result which have been described, the author could provide advice to investors or capital market players in particular and the author would continue these research in order to improve it.

1) From these resulting description of responsiveness and contribution portion of determinant factors that have been described, it is hoped that investors or capital market players could observe when shock or instability was occurs to these variables as a basis for risk mitigation in placing their investment.

2) Macro variables play an important role in sustainability of domestic economy, including these capital market. Macro economic variable stability will strengthen the foundations of domestic economy so as to create a conducive environment for investment. Macro 
economic stability is an important factor used by investors in making investment decisions.

3) Researchers could use a variety of other independent variables either by maintain this existing variables or adding new variables that aimed to seeing the impact on other sectors. The research period was carried out by considering the changes that occur in macro economic factors in economy occured.

\section{REFRERENCES}

Asih, N. W. S., \& Akbar, M. (2017). Analisis Pengaruh Inflasi, Suku Bunga, Nilai Tukar (Kurs) Dan Pertumbuhan Produk Domestik Bruto (Pdb) Terhadap Indeks Harga Saham Gabungan (Ihsg) Studi Kasus Pada Perusahaan Properti Yang Terdaftar Di Bursa Efek Indonesia. Jurnal Manajemen dan Akuntansi, 17(1).

Bustami, F., \& Heikal, J. (2019). Determinants of Return Stock Company Real Estate and Properti Located in Indonesia Stock Exchange. International Journal of Economics and Financial Issues, 9(1), 79.

Fardiansyah, A., Siagian, V., \& Sihombing, P. (2018). Determinan Indeks Sektor Pertambangan Di Bei Periode 2012-2017. Prosiding Seminar Nasional Cendekiawan, 847-852.

Nuryasman, N., \& Yessica, Y. (2017). Determinan harga saham sektor properti dan real estat di bursa efek indonesia. Jurnal Manajemen, 21(2), 270-281.

Rohmanda, Deny. (2014). Pengaruh Kurs Rupiah, Inflasi Dan Bi Rate terhadap Harga Saham (Studi pada Indeks Sektoral Bursa Efek Indonesia Periode 2005-2013). Jurnal Administrasi Bisnis, 13(1).

Sihombing, P., Amalia, D. (2014). AnalisisKemampuan Stock Selection dan Market Timing Pada Reksadana Saham di Indonesia. Jurnal Pasar Modal dan Perbankan, II(2).

Sukirno, Sadono. (2009). Makro Ekonomi Teori Pengantar. Jakarta : PT Raja Grafindo Persada.

Teguh, M. (2005). Metodologi Penelitian Ekonomi, Jakarta, Raja Grafindo.

Thobarry. (2009). Analisis Pengaruh Nilai Tukar, Suku Bunga, Laju Inflasi Dan Pertumbuhan GDP Terhadap Indeks Harga Saham Sektor Properti (Kajian Empiris Pada Bursa Efek Indonesia Periode Pengamatan Tahun 2000 - 2008). Tesis. Universitas Diponegoro, Semarang.

Triyono. (2008). Analisis Perubahan Kurs Rupiah Terhadap Dollar Amerika. Jurnal Ekonomi Pembangunan, 9(2), 156-167.

Wardani, D. K., \& Andarini, D. F. T. (2016). Pengaruh Kondisi Fundamental, Inflasi, dan Suku Bunga Sertifikat Bank Indonesia Terhadap Harga Saham (Study Kasus Pada Perusahaan Real Estate dan Properti yang Terdaftar di Bursa Efek Indonesia Tahun 2010-2013). Jurnal Akuntansi, 4(2), 77-90.

Sihombing, Pardomuan. (2018). Corporate Financial Management. Bogor: IPB Press. 